\title{
1 \\ A Fountain in the Square
}

I begin my perceived existence in a railway carriage. I do not as yet know precisely who I am or how old. I am still a bundle of feelings who parrots the talk of her parents. I am so little and my mother is so tall beside me in her soft, grey, black-flecked coat. I lean against her reassuring, warm and fragrant body. We travel backwards. The train wheels rumble along the lines below us. On my lap is a light-green Iranian tea set in baked clay. I love it. I love it because my father gave it to me when we said goodbye by the Caspian Sea.

Fragments of my remembered past are so vivid that I enter particular episodes of that life as if I were there now, at this very moment, on an island floating in its own enclosed immutable space and time. But then the larger story unfolds gently in its telling. All my personal islands are linked to other people and large communities over whom I, as a child, had no decisive control.

Now I am standing near a window in my grandmother's apartment in Breslau. It is well above ground and overlooks the square below. Children ride their tricycles around an empty fountain. Some leap in and out of its dry basin. There is a statue, identified for me as King Neptune, in the centre of it. I long to join the play. My young aunt is brushing my hair and promises to take me downstairs. The sky is a bright blue. The snow has not yet come. 
Uncle Otto takes me to see the Konditorei (sweets and cake shop) nearby. In the shop window a whole gingerbread village is covered in sugar snow. Who buys such large treats? The scene is too perfect to eat.

One day I am surrounded by crowds in a Breslau square. The day is grey. Marching people enter from a side street. Trumpeters perform lively music as they move along. Some marchers carry large decorated flags. Children swarm beside the procession. I also leap along with them to the sound of the music. There is nothing sinister in what I observe. But mother tells me to come quickly, and takes me away.

Early one morning, in grandmother's flat, my bent-over Omi (grandmother's mother) brings a cup of warm milk to the cot in which I am standing. She is gentle and kind to me.

Now we are in Vienna with my father's people. We walk across a bridge that spans the Danube. I am frightened of the water below. My grandfather holds my hand lovingly, securely. I look up at the patterns made by the bridge. My heart soars with these strong supports and the patterns they make. One day I will be told by my father that the bridge is called a 'hanging bridge'. So grand is the memory that I look for it many years later. But I cannot find it again.

My father's sisters take mother and me to the Prater, the Luna Park of Vienna. At the entrance is a Watschen Mann (ear-cuff man), a large rubber doll in the shape of a man. People come and whack him across the face. A needle inside a tube tells how strong the blow has been. I feel sick as I watch a strong man hit the Watschen Mann across his face. Then, in a little open train we move through a tunnel and observe amazing scenes in grottoes. Girls hang from hooks by their plaits above burning coals, while devils with pitchforks stand below them. They do not move. I shiver as the train moves on.

Mother then takes me up on the Ferris wheel.

Later in life I was able to date these scenes, these unconnected fragments of memory so solidly fixed in my mind over the years. They happened when my mother took me back home to her folk in Germany for Christmas. Six months later, in 1938, my brother was born in Iran's Tehran just before I turned three. Although these are my only memories between the ages of two-and-a-half and three, they are not without their implications for the future. They may well illustrate that in early childhood a sudden 
change of residence helps to anchor memories that are governed by feelings and perceptions rather than by thought. While this set of images has become a fixture of my mind, labelled as 'my first memories', I assume that they were once even simpler. Over time they grew in subtlety and size. Fashioned as my own seamless garment, they may have in fact been sewn from the unremembered talk of others. My mother forgot some things I recall, while she remembered different parts of this story for much longer. 
This text is taken from At Home in Exile: A Memoir, by Helga M. Griffin, published 2021 by ANU Press, The Australian National University,

Canberra, Australia.

doi.org/10.22459/AHE.2021.01 